\title{
INTERREGIONAL TOURISM COOPERATION: A EUROPE CASE STUDY
}

\author{
T. Studzieniecki ${ }^{1}$, J. R. R. Soares ${ }^{2}$ \\ Gdynia Maritime University ${ }^{1}$, Universidade da Coruña ${ }^{2}$ \\ jaksonrenner@yahoo.com.br \\ Received 25/10/2016 - Accepted 28/06/2017 \\ DOI: $10.15628 /$ holos.2017.5263
}

\begin{abstract}
The purpose of this article is the answer of the question if interregional cooperation supported by economic policy of UE fosters tourism development and if yes in what way. The relation between tourism and interregional cooperation is relatively seldom analysed in comparison with other strands of territorial cooperation such as crossborder and transnational cooperation. This results from specific philosophy of interregional cooperation.

In order to achieve the purpose of the paper it was necessary to present the system of interregional cooperation management and model of tourism in European Union. The paper analyses the period 2007 2013 when INTERREG IVC provided funding for interregional cooperation across Europe.
\end{abstract}

The overall objective of the INTERREG IVC Programme was to improve the effectiveness of regional policies and instruments with special attention to the areas of support such as:

- innovation and the knowledge economy, - $\quad$ environment and risk prevention.

Tt could be assumed that it had been possible to include tourism in tourism projects implemented within Interreg IV C. To prove it the qualitative and quantitative analysis of 204 projects divided into 12 themes has been done. Aditionally the database of good practices was analyzed. The analysis of its documents allowed to identify 60 tourism-related good practices. These practices focused on cultural and sustainable tourism.

KEYWORDS: tourism, European Union, regional policy, interregional cooperation, INTERREG. 


\section{INTRODUCTION}

Europe has recently seen a rapid growth in tourism [Fesenmaier, O'Leary, Uysal 2013, p. $\mathrm{XV}$ ] and hospitality industry [Grobelna, Marciszewska 2016]. Tourism is becoming an increasingly important factor for social and economic development [Sharma 2004, p. 1]. Due to this reason the European Union supports tourism development stronger and stronger through numerous assistance programmes [Guide (...) 2016], in particular territorial co-operation programmes and neighbourhood policy programmes [Faby 2016, Studzieniecki 2015, Studzieniecki 2016].

The relationships between tourism and programmes of cooperation beyond borders were documented in extensive literature dealing with the subject. Interregional cooperation programmes are, however, an exception. It is stressed that they are the 'youngest' INTERREG programmes [Fact Sheet 2015] with the smallest financial support [Balaz 2006, p. 102]. Studies on tourism in interregional cooperation programmes focus mainly on case studies [Mc Keever, Larwood, Mc Kirdy 2006, p. 191, Deffner, Metaxas 2010, p. 67, Perosa, Menotti, Saraceni 2008, p. 80], omitting the issue of systems analysis.

Thus, the question whether interregional cooperation programmes support tourism development, and if they do, how and to what extent, needs to be answered.

To answer this question, a research model was created (Figure 1).

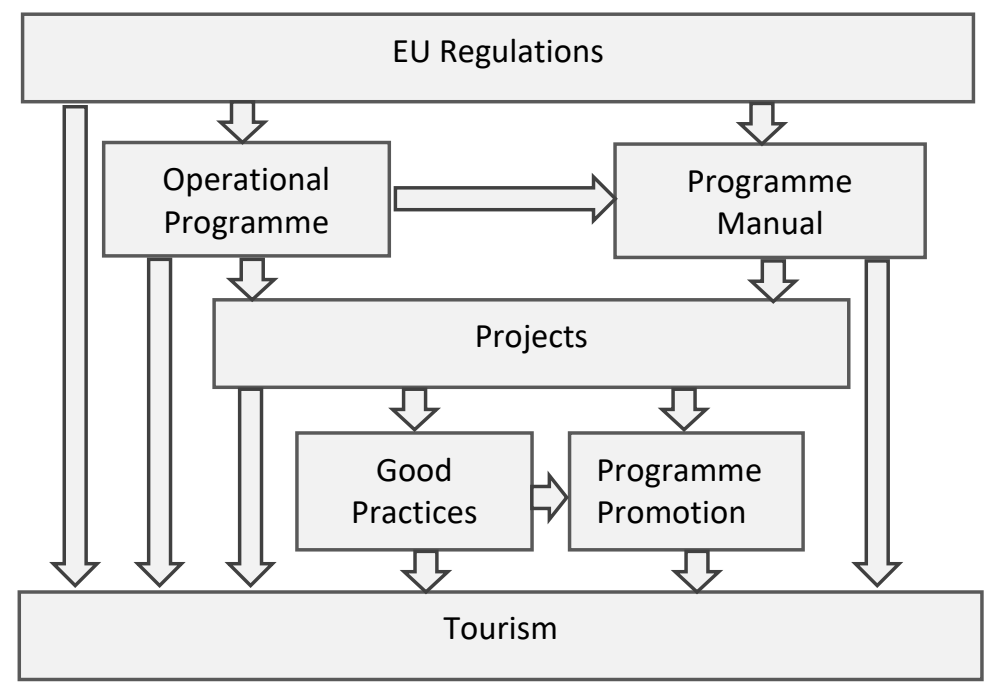

Figure 1: Research model

The model shows the key research groups and a sequence of analytical works allowing to identify the role of the programme in tourism development.

\section{THE ORIGIN AND PURPOSE OF INTERREGIONAL COOPERATION}

Interregional cooperation is, together with cross-border and transnational cooperation, one of the forms of territorial cooperation supported by the European Union [Celata, Coletti 2015, p. 109, Morata, Noferini 2013, p. 174, Schutze 2015, p. 851]. Before the term "territorial cooperation" appeared in EU official documents, other terms were used, including "cooperation beyond borders" [Studzieniecki 2015, p. 16] or "transboundary cooperation" [Duhr, Colomb, 
Nadin 2010, p. 354]. These terms are also used today both as the synonyms of territorial cooperation and as broader terms [Terem 2010, p. 47. Marcut 2015 p. 25]. "European Commission places much emphasis on softening borders as well as solving border-related problems, by enabling and promoting different forms of cooperation beyond borders" [Haselsberger 2014, p. 505].

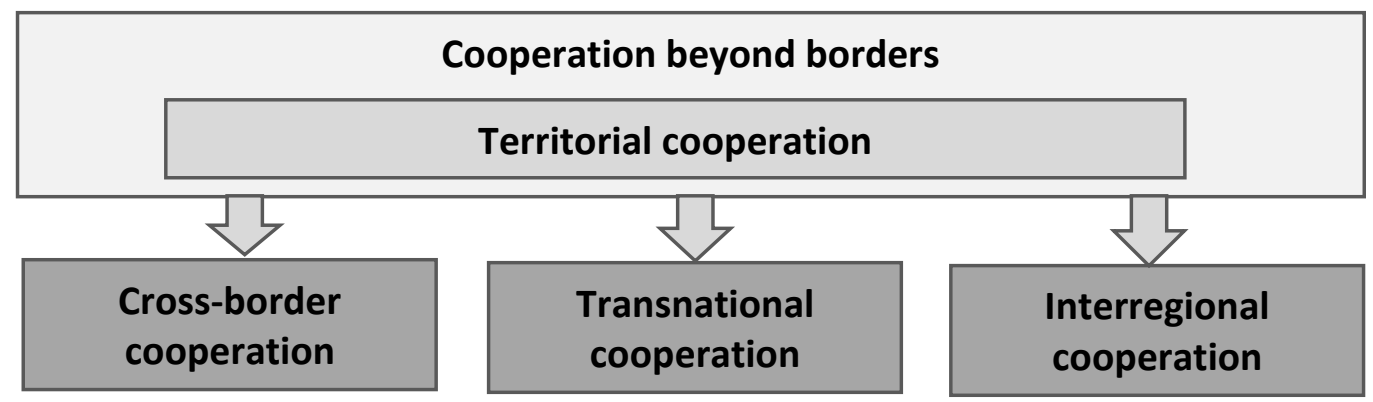

Figure 2. Types of cooperation beyond borders

Interregional cooperation covers mostly subnational entities of international relations [Williams 2012, p. 161], although some authors use this term in relation to cooperation between countries [Kutukov 2006, s. 8]. However, EU states are no longer the most important actors on the international stage.

It should be noted that by the end of the 20th century international relations were greatly decentralized, and the international system was filled with subnational entities. Government administration allowed local government administration to cooperate at international level [Szymański 2011, p. 90]. EU regions enhanced cooperation with their counterparts from third countries. The cooperation, which was originally cross-border cooperation, became international. The institutionalisation of regional cooperation in Europe began. In 1971 the Association of European Border Regions was established. In 1985 the Council of European Regions was set up, two years later it was replaced by the Assembly of European Regions. The Standing Conference of Local and Regional Authorities of Europe started to operate under the auspices of the Council of Europe. The Conference turned into the Congress of Local and Regional Authorities of Europe. The Congress became a specialised institution representing local and regional authorities. It is a consultative and advisory body. The key issues of interregional cooperation were stipulated in 2 documents [Castro 1999, p. 105]:

1. European Charter of Local Self-government [1985],

2. European Charter of Regional Self-government [1997].

The first of the documents emphasised the role of the Council of Europe in enhancing the interaction between EU member states and their local self-government entities. It stressed the significance of local bodies as an important element of the democratic system. It determined the rules of establishing international cooperation by local self-government [Buczkowski, Żukowski 2014, p. 29]. According to the Charter's provisions, local bodies, in the course of their competences, obtained the right to cooperate with other local bodies. They also became entitled to associate with other local bodies to carry out tasks of common interest. It must be emphasised that despite the general character of this Charter, with few provisions related directly to the international cooperation of local self-government bodies, compliance with the Charter's provisions significantly facilitated establishing cooperation between local self- 
government entities and foreign partners. This is because the Charter created legal basis for such cooperation and harmonised standards of establishing such cooperation [Perkowski 2012, p. 16].

The other document clarified the rights of regions in establishing international cooperation. According to the provisions it sets out, a region has the right to conduct its own policy and international cooperation. The term "interregional cooperation" was introduced. Such cooperation was considered "a valuable and necessary contribution to the construction of Europe" [European Charter of Regional Self-government, 1997]. According to experts [Kentnowska 2012, p. 267], the success of such cooperation depends on the system of domestic law and the political commitment of the state directly concerned by such cooperation.

\section{INTERREGIONAL COOPERATION IN THE COMMUNITY INITIATIVE "INTERREG"}

Interreg as a financial instrument was introduced in 1990 primarily to compensate for the introduction of the Single Market and soften the blow for border regions [Wassenberg, Reitel Peyrony 2015, p. 3]. The implementation of INTERREG was preceded by 14 pilot projects. They were designed to overcome structural development difficulties in border regions in two areas [Fact Sheet 2015, p. 2]:

1. institutional separation of border communities, where economic and social separation prevents coherent management of the ecosystems,

2. actual peripheral location of cross-border regions in relation to their respective national economic centres.

The Community initiatives INTERREG I and INTERREG II primarily focused on cross-border cooperation. They sought to involve local and regional stakeholders in eliminating barriers to the free movement of goods, people, capital and services, by allowing them to develop cross-border projects.

In 2000 under the initiative INTERREG III a new trend appeared for the first time, i.e. "interregional cooperation". This is the youngest component of INTERREG. The core idea of interregional cooperation - inherently different from cross-border or transnational cooperation is that regions have much to learn from each other in terms of regional development policy. The programme financed the exchange of experience and good practice in Structural funds across Europe. During the programming period 2000-2006, INTERREG IIIC was open to a wide range of themes linked to regional development policy: from thematic cooperation Research and Technological Development (RTD), Information Society, Regional Planning or Transport to cooperation between Objective 1 and 2 regions or INTERREG programmes. The INTERREG IIIC programme helped 2634 regional partners in 267 project exchanges to improve their regional policies. [Morgan 2010, p. 12]. Another editions of interregional cooperation programmes (Interreg IVC, Interreg Europe) were the components of a new goal in cohesion policy - European Territorial Cooperation (Figure 3). 


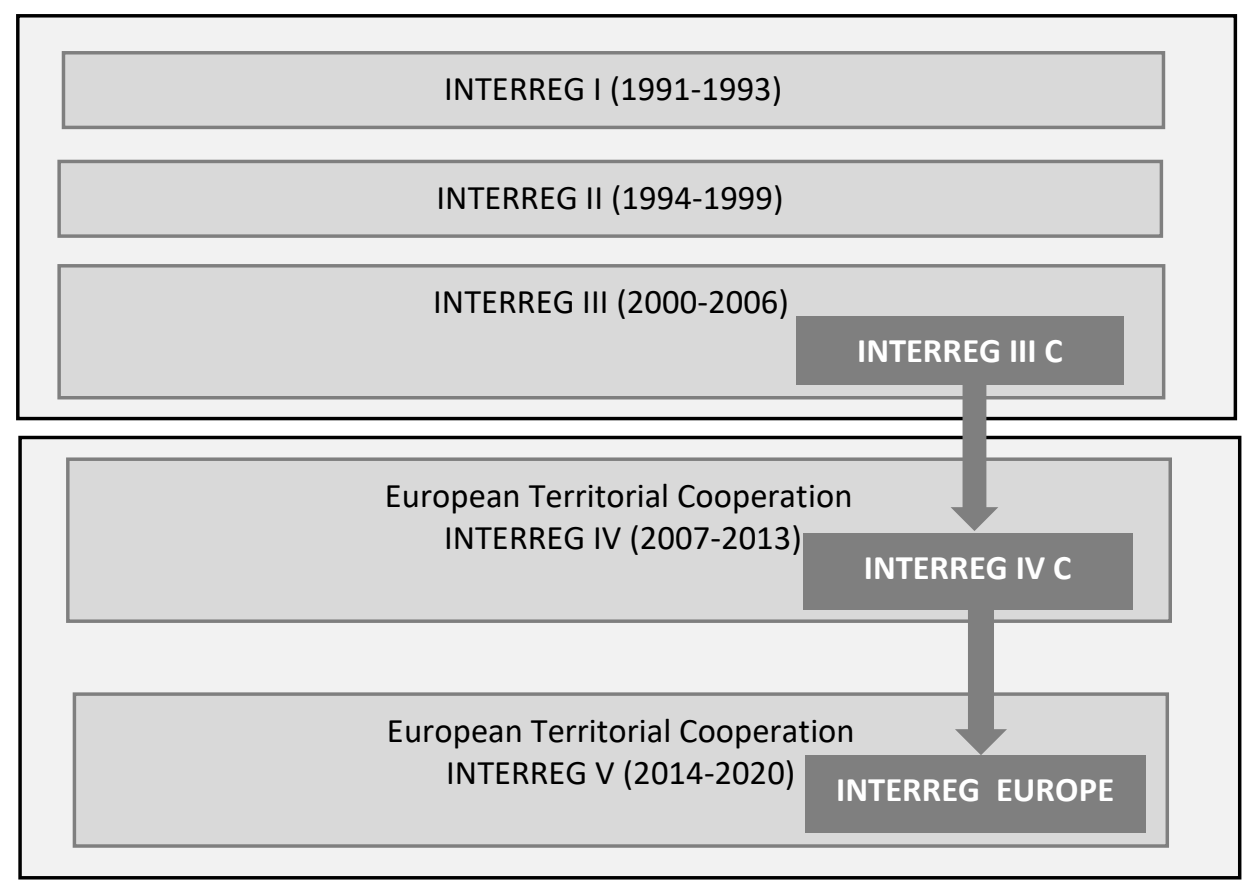

Figure 3 The evolution of interregional cooperation programmes

The INTERREG budget (Figure 4) progressively increased from EUR 4.875 billion (INTERREG I) to EUR 8.9 billion (INTERREG V). $2.52 \%$ of the structural fund budget was allocated to INTERREG IV while $2.75 \%$ of the structural fund budget was allocated to INTERREG V.

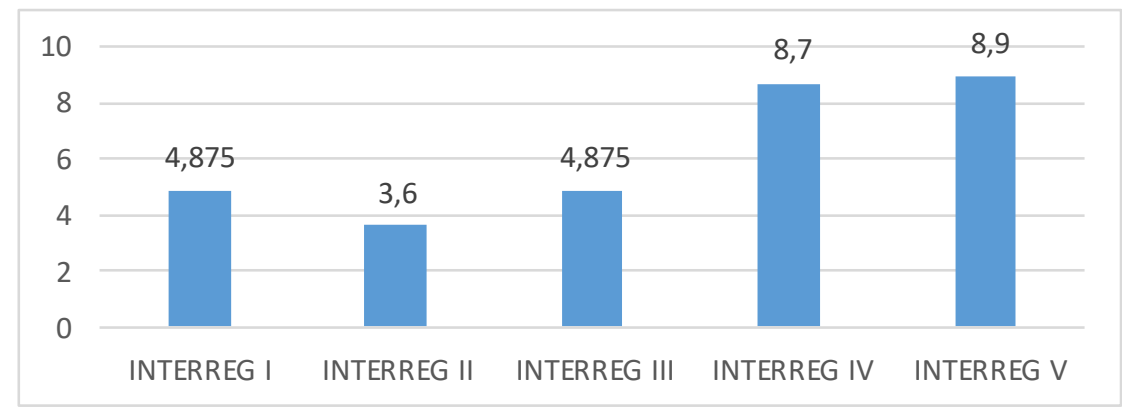

Figure 4. INTERREG budget (EUR billion)

The budget for interregional cooperation programmes progressively increased as well (Figure 5). However, it must be emphasised that out of the three components of INTERREG the smallest support was allocated to interregional cooperation. INTERREG IIIC received $6 \%$ of the INTERREG III budget, but the next two editions received only $4 \%$ of the budget.

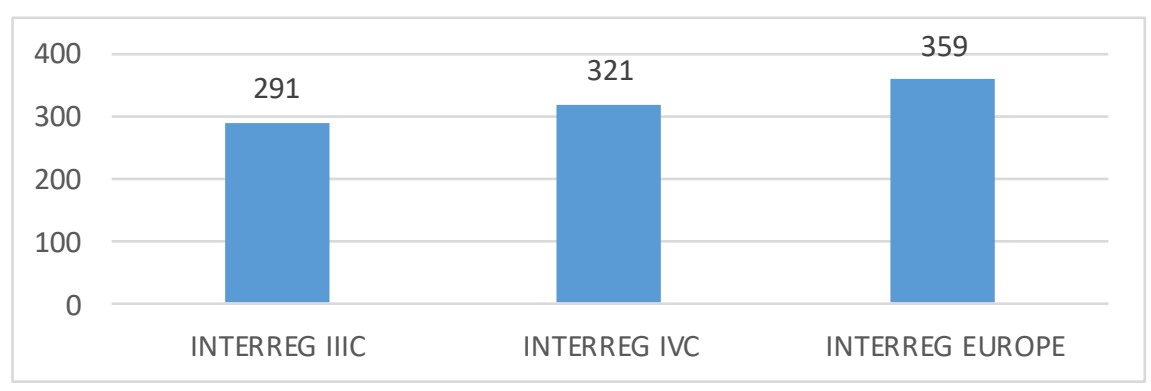

Figure 5. Budget of territorial cooperation programmes (EUR million) 


\section{THE PREMISES, OBJECTIVES AND COMPLETION OF INTERREG IV C}

The objective of the Interregional Cooperation Programme was to support the cooperation between regional and local authorities from 27 EU states as well as Norway and Switzerland (Figure 6).

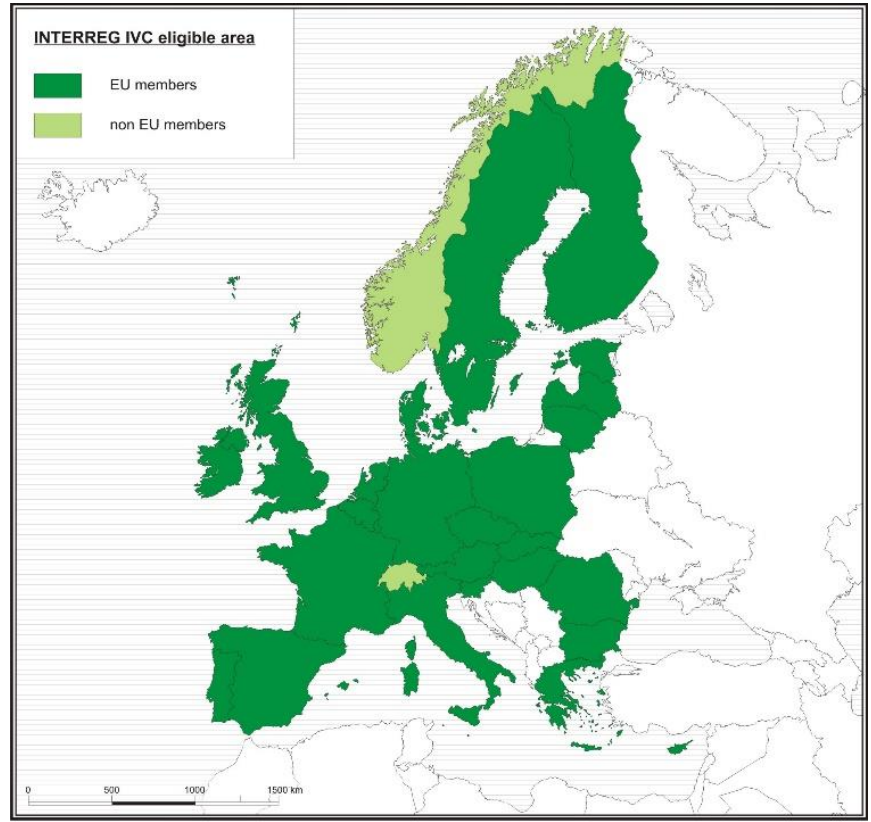

Figure 6 The eligible INTERREG IV C area

The idea of the programme was to implement projects for exchanging and sharing experience and developing concepts and tools together, which would improve the effectiveness of regional development policies and would contribute to the modernisation of the economy. According to the Community strategic guidelines on cohesion policy for the years 2007-2013, the objective of the programme was to support the EU strategy for growth and jobs [Interregional Cooperation Programme INTERREG IVC].

The programme was an important instrument for implementing the EU initiative "Regions for economic change". This initiative supported networks of regions and cities that developed and tested optimal actions for modernising the economy through projects that implemented the EU programme for growth and jobs. The projects were to popularize such actions in all regions to strengthen their sustainable growth and reduce economic disparities between them. Table 1 shows the programme's priorities and strategic objectives.

Table 1: INTERREG IV C priorities and operational objectives

\begin{tabular}{|l|l|}
\hline Priority & Operational objectives \\
\hline P1. & $\begin{array}{l}\text { 1. Improving the capacity of regions for strengthening research, technology and innovation; } \\
\begin{array}{l}\text { Innovation } \\
\text { and } \\
\text { knowledge } \\
\text { economy }\end{array}\end{array}$ \\
$\begin{array}{l}\text { 2. Promoting and enabling entrepreneurship and the development of new business initiatives in } \\
\text { innovative; }\end{array}$ \\
$\begin{array}{l}\text { 3. Facilitating businesses, and in particular SMEs, to develop and grow in a more sustainable and } \\
\text { innovative way through the transfer of specific services and the creation of shared facilities; }\end{array}$ \\
\hline
\end{tabular}




\begin{tabular}{|c|c|}
\hline & $\begin{array}{l}\text { 4. Helping to restructure regions most heavily dependent on traditional industries, including } \\
\text { renewal of industrial zones for new business; } \\
\text { 5. Promoting the use of new information and communication technologies by businesses, public } \\
\text { services and the general public, especially in rural areas; } \\
\text { 6. Improving regional policies for employment, skills development, training and education; } \\
\text { 7. Creating the necessary framework conditions for regional economies to adapt to major socio- } \\
\text { economic changes, notably globalisation and demographic change. }\end{array}$ \\
\hline $\begin{array}{l}\text { P2. } \\
\text { Environment } \\
\text { and risk } \\
\text { prevention }\end{array}$ & $\begin{array}{l}\text { 1. Developing plans and measures to prevent and cope with natural and technological risks; } \\
\text { 2. Promoting the enhancement of sustainable water management activities; } \\
\text { 3. Promoting the development of sustainable Waste prevention and management activities and } \\
\text { the movement to a recycling society; } \\
\text { 4. Promoting the development of actions linked to biodiversity and the preservation of natural } \\
\text { heritage, especially in NATURA } 2000 \text { sites and promoting the development of sustainable } \\
\text { coastal management activities; } \\
\text { 5. Stimulating energy efficiency and the development of renewable energies as well as better } \\
\text { coordinated efficient energy management systems and promoting sustainable transport; } \\
\text { 6. Enhancing the attractiveness of the territory in support of socio-economic development and } \\
\text { sustainable tourism by protecting the cultural heritage and landscape. }\end{array}$ \\
\hline $\begin{array}{l}\text { Technical } \\
\text { assistance }\end{array}$ & $\begin{array}{l}\text { 1. Supporting project generation and providing advice to project applicants; } \\
\text { 2. Ensuring the evaluation of applications, preparing the approval decisions and contract } \\
\text { approved projects; } \\
\text { 3. Ensuring monitoring of and advice to running operations; } \\
\text { 4. Ensuring capitalisation of operations' results for both types of intervention; } \\
\text { 5. Organising meetings and events for applicants, partners, auditors, experts, Member States and } \\
\text { other bodies to inform them about the programme, to discuss specific aspects of its } \\
\text { implementation, disseminate and capitalise on operations' results; } \\
\text { 6. Reporting to the Member States and the European Commission. }\end{array}$ \\
\hline
\end{tabular}

Source: own work based on: [Interregional Cooperation Programme INTERREG IVC]

Ten themes relating to the operational objectives were identified in priorities P1 and P2 (tab. 2). These themes were later used in the classification of projects carried out as part of the programme.

Table 2: INTERREG IVC priorities and themes 


\begin{tabular}{|l|l|}
\hline Priority & Themes \\
\hline P1. & $\begin{array}{l}\text { 1. Innovation, research and technological development (IR/TD) } \\
\text { 2. Entrepreneurship and SMEs (E/SMEs) } \\
\text { Innovation and }\end{array}$ \\
knowledge economy & $\begin{array}{l}\text { 3. Information Society (IS) } \\
\text { P2. Employment, Human Capital and Education (EHC/E) }\end{array}$ \\
Environment and risk & $\begin{array}{l}\text { 1. Natural and technological risks, climate change (NTR) } \\
\text { prevention }\end{array}$ \\
& $\begin{array}{l}\text { 3. Water management (WM) } \\
\text { 4. Eiodiversity and preservation of natural heritage; air quality (B/PNH) }\end{array}$ \\
& 6. Cultural heritage and landscape (CH/L) \\
\hline
\end{tabular}

Source: own work based on [Interregional Cooperation Programme INTERREG IVC]

The Programme INTERREG IV C supported two different types of interventions:

1. "Regional Initiative Projects" (RIP) initiated by regional actors aiming to exchange experience in a specific policy field in order to identify good practice and to develop new tools and approaches for implementation.

2. "Capitalisation, including Fast Track projects" (CP) in order to ensure that good practice identified, for instance, by the regional initiative projects mentioned above, finds its way into the Convergence, Regional Competitiveness and Employment and European Territorial Cooperation programmes.

Four out of 86 priority themes were selected to be implemented, and relevant amounts were allocated to them (tab. 3).

Table 3: Priority themes and amounts for their implementation.

\begin{tabular}{|l|l|l|}
\hline Priority theme & Code & Amount (Euro) \\
\hline Other measures to stimulate research and entrepreneurship in SMEs & 09 & $176,726,969$ \\
\hline Other measures to preserve the environment and prevent risks. & 54 & $125,315,487$ \\
\hline Technical Assistance: preparation, implementation, monitoring and inspection & 85 & $14,354,791$ \\
\hline Evaluation and studies; information and communication & 86 & $4,924,515$ \\
\hline
\end{tabular}

Source: own work based on: [Interregional Cooperation Programme INTERREG IVC, p. 94]

Institutions from France played a leading role in managing the programme. All major functions were given to them (Figure 7). 


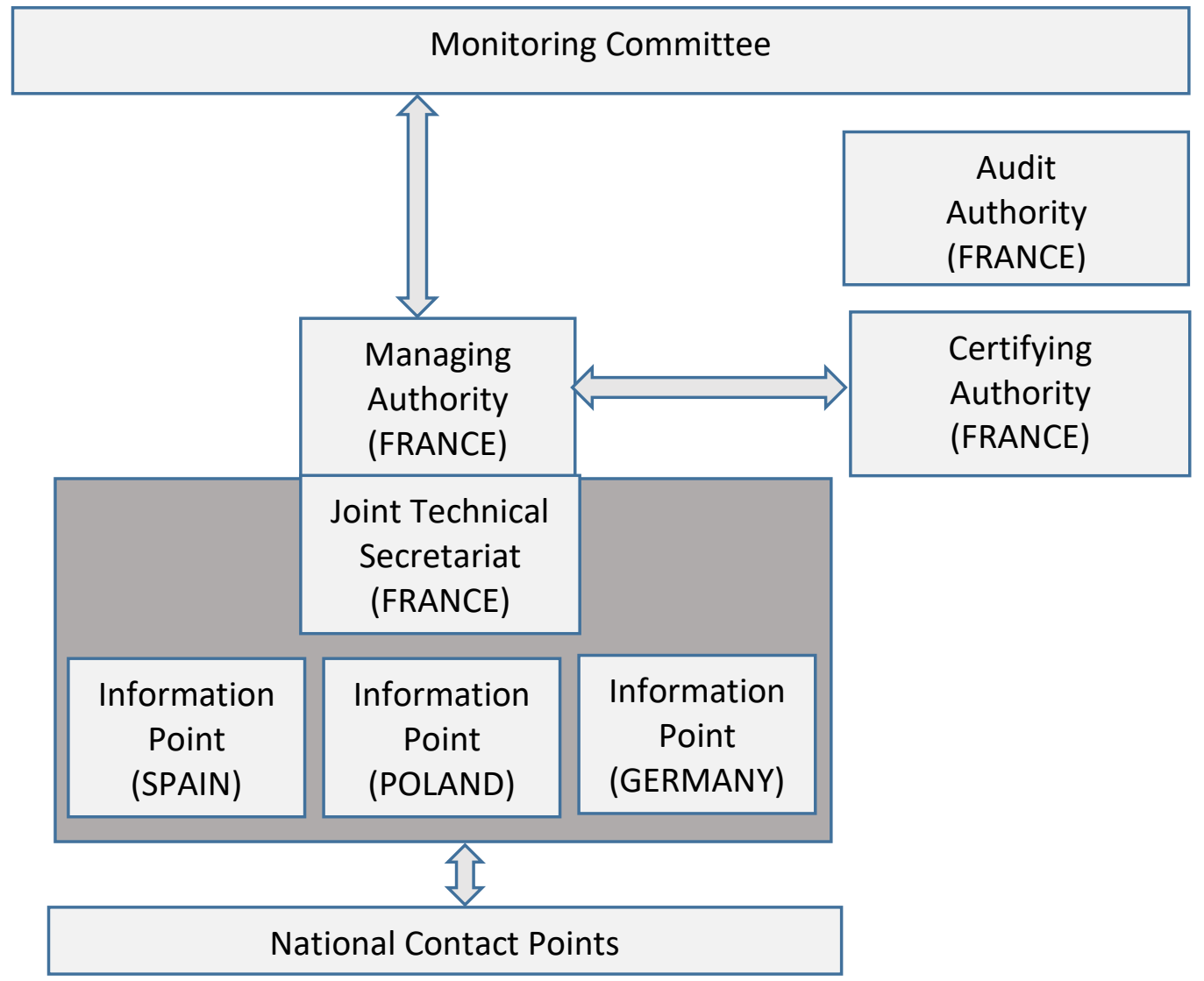

Figure 7 INTERREG IVC management model

There were four application rounds in the programme. The majority of applications were sent from Italy (2133), Spain (1624), and Greece (1510). Among EU states, the fewest number of applications was sent from Luxembourg (11). In total, 204 projects were completed, including 2276 partners. 90\% out of 271 administrative regions (NUTS 2) participated in the programme.

The projects implemented under INTERREG IVC differed considerably from the projects implemented in other territorial cooperation programmes. In particular, they were not investment projects. The programme focused on the identification, analysis and dissemination of good practices by public authorities, in order to improve the effectiveness of regional and local policies. Projects supported under this programme had demonstrate how they built on the stock of experiences gained under past or existing regional development programmes including Structural Funds programmes.

The activities within the programme [Interregional Cooperation Programme INTERREG IVC] had to respect the following three fundamental conditions:

1. Relevance to the programme

All activities have to be in line with the overall objective of the programme and should clearly contribute to the improvement of the regional or local policies tackled by the project.

2. Interregionality

The interregional character of the activities has always to be demonstrated in projects. Activities of pure local character cannot be supported under INTERREG IVC. The interregionality of pilot actions is clear when these actions are directly related to the transfer of practice from a 
region to another region. Interregionality means also the development of new approaches benefiting the whole partnership

\section{Additionality}

The added-value of the proposed cooperation has to be clearly demonstrated. Indeed, the activities proposed to the INTERREG IVC programme have to be different from the normal and regular tasks of the partners involved in the project. In particular, the pilot actions have to represent additional activities that would not be carried out without the support of the INTERREG programme.

\section{TOURISM ISSUES IN THE OPERATIONAL PROGRAMME INTERREG IVC}

Tourism issues were not identified in 4 out of 86 priority themes accepted for implementation. They did not appear in 2 priorities in this programme. They appeared, however, in operational objective 6 in the "Environment and risk prevention" priority:

"Enhancing the attractiveness of the territory in support of socio-economic development and sustainable tourism by protecting the cultural heritage and landscape" [Interregional Cooperation Programme INTERREG IVC].

In addition, some selected tourism-related issues were in the content of the programme.

In the analysis of the situation of the support area, in the part about the environment, it was stated that "good management of tourist and cultural resources and landscapes is the best way to combine preservation and conservation with economic promotion". It was emphasised that slowing down the biodiversity decline may be beneficial for the tourism sector.

The authors of the programme assumed that innovative methods showing and providing cultural heritage and landscapes can be a basis for the further use of cultural resources for information, educational and research purposes and for the sustainable development of the tourism sector.

In the SWOT analysis, in the part about opportunities, it was concluded that "innovative ways to make natural and cultural heritage more visible and accessible provides the basis for further exploiting natural and cultural resources for educational purposes, research, tourism and creative businesses".

The programme listed tourism organizations as potential beneficiaries. Tourism was identified as the subject matter of future projects, both "Regional Initiative Projects (RIP)" and "Capitalisation, including Fast Track projects".

\section{TOURISM ISSUES IN THE PROGRAMME MANUAL}

The Programme Manual [2008] advised great caution in dealing with tourism issues as part of projects. "The above topic has to be tackled with care under the INTERREG IVC programme". Elsewhere it even discouraged from doing so. "The development of tourism activities as such would not be relevant to the programme". In the explanatory statement the authors of the manual claimed that other EU programmes were dedicated to tourism. 
At the same time it was allowed to deal with tourism issues in some special cases, under two conditions:

1. Projects tackling this topics would therefore has to clearly describe the added-value of the proposal compared to past or existing initiatives in that domain.

2. Topics of tourism would need to be tackled in the framework of the Lisbon and Gothenburg agendas (e.g. strategies related to sustainable tourism) to demonstrate their relevance to INTERREG IVC.

\section{TOURISM IN INTERREG IVC PROJECTS}

Tourism is an issue which appears very often in projects supported by EU funds. The term "tourism projects" can be used in relation to projects tackling tourism issues. To identify tourism projects among all projects in a group, a specific criterion must be defined (Figure 8). In this classification an objective criterion was chosen, i.e. the word "tourism" in the description of project actions. Descriptions from the INTERREG IV C database were used for this purpose.

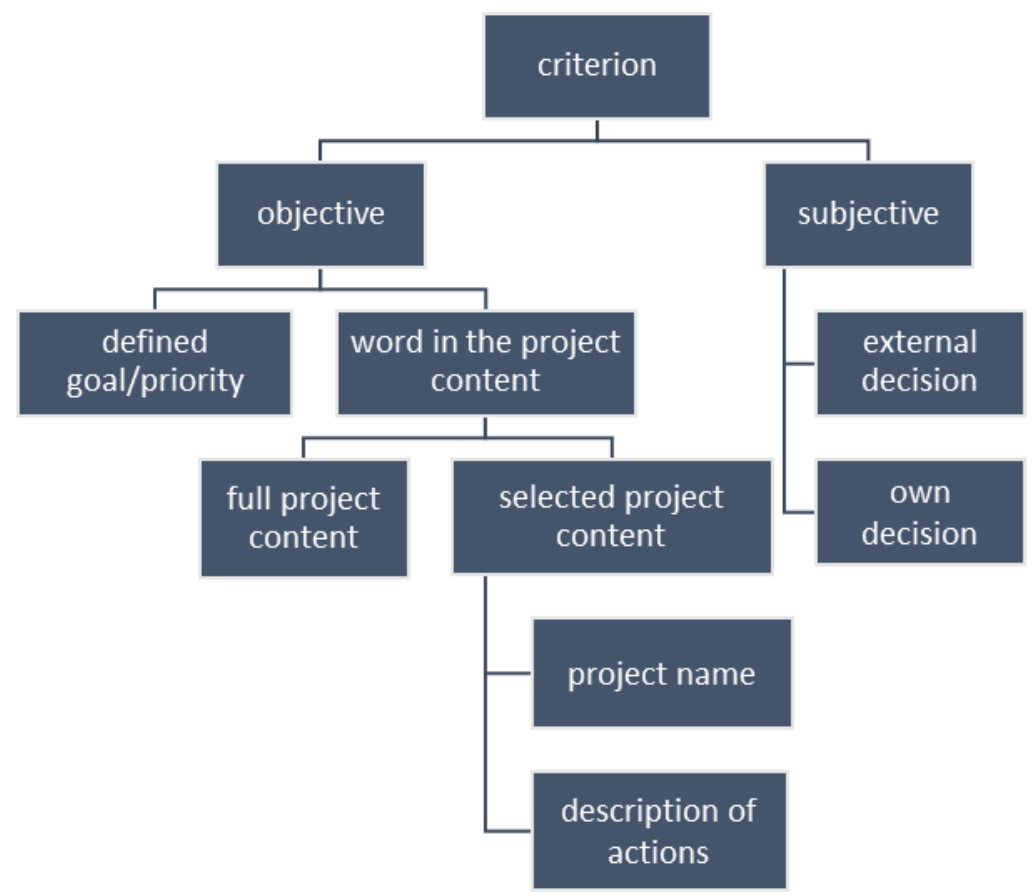

Figure 8: Criteria for the identification of tourism projects

Based on this criterion 30 projects were identified. The coordinators of these projects were from 13 countries. One country was outside the EU (Norway) and one country was from Eastern Europe (Poland). Figure 9 shows the number of projects coordinated by these countries. 


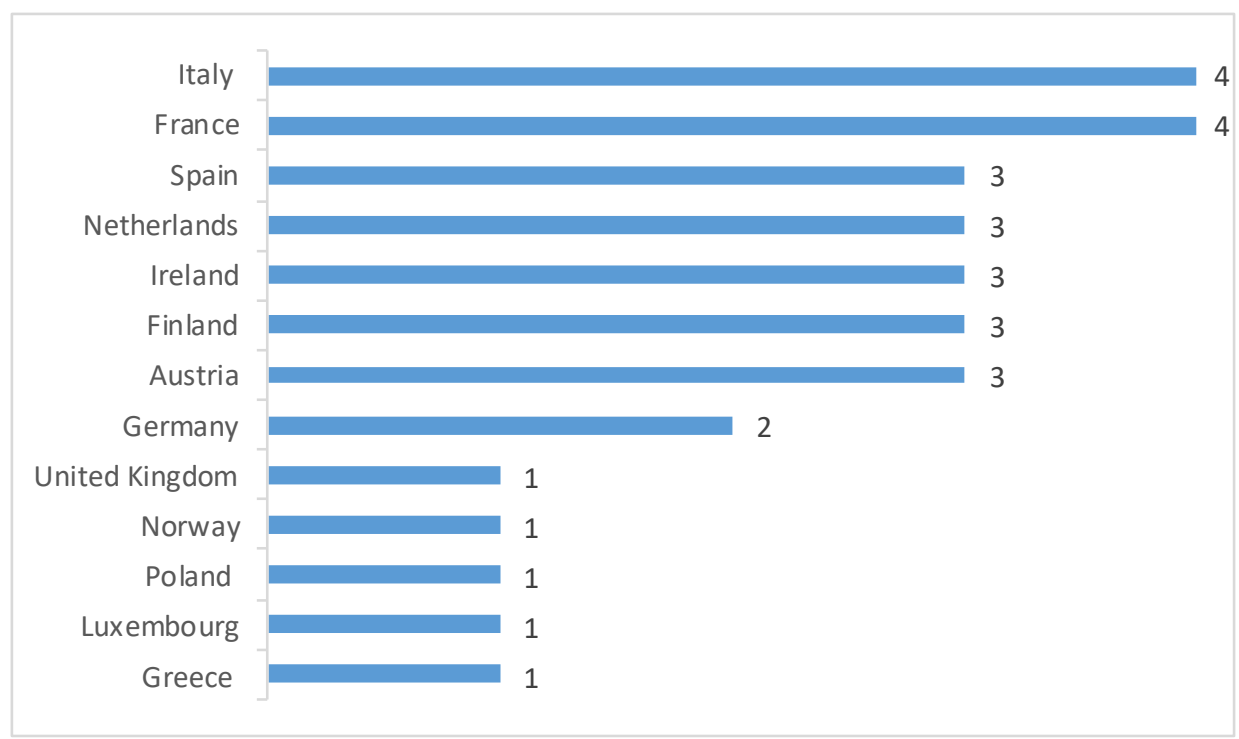

Figure 9: Number of tourism projects coordinated by the countries

The coordinators were mostly regional institutions (50\%), then local institutions (23.33\%), national institutions (13.33\%), and European institutions (13.33\%). The majority of the coordinating institutions had the status of government institutions or local self-government institutions. Authorities of border regions predominated among regional authorities (table 4).

Three out of four institutions at European level were associations. Two institutions associate regions, another institution associates experts on the environment and the development of coastal areas. The fourth institution is the European Institute of Cultural Routes; it plays an important role in the development of cultural tourism.

Two institutions coordinating tourism projects can be defined as tourism institutions: Polish Tourism Development Agency, Regional Committee for Tourism Development of Auvergne.

Table 4: Tourism projects and their coordinators

\begin{tabular}{|c|l|l|l|l|l|}
\hline No. & Abbreviation & Name & Coordinator & Country & Region \\
\hline 1. & B2N & $\begin{array}{l}\text { Business to Nature - } \\
\text { Interregional Approach } \\
\text { to SMEs and } \\
\text { Entrepreneurship } \\
\text { Policies in Natural } \\
\text { Areas }\end{array}$ & $\begin{array}{l}\text { Polish Tourism } \\
\text { Development } \\
\text { Agency }\end{array}$ & Poland & Mazowieckie \\
\hline 2. & CERTESS & $\begin{array}{l}\text { European Cultural } \\
\text { Routes - Transfer } \\
\text { Experiences, Share } \\
\text { Solutions }\end{array}$ & $\begin{array}{l}\text { European Institute of } \\
\text { Cultural Routes }\end{array}$ & $\begin{array}{l}\text { Luxem- } \\
\text { bourg }\end{array}$ & $\begin{array}{l}\text { Luxembourg } \\
\text { (Grand-Duché) }\end{array}$ \\
\hline 3. & CHARTS & $\begin{array}{l}\text { Culture and Heritage } \\
\text { Added value to } \\
\text { Regional policies for } \\
\text { Tourism Sustainability }\end{array}$ & $\begin{array}{l}\text { Municipality of } \\
\text { South Pelion, } \\
\text { Argalasti }\end{array}$ & Greece & Thessalia \\
\hline
\end{tabular}




\begin{tabular}{|c|c|c|c|c|c|}
\hline 4. & CLUSTERIX & $\begin{array}{l}\text { Clusters for European } \\
\text { Innovation Cross- } \\
\text { Linking }\end{array}$ & $\begin{array}{l}\text { Ecoplus. The } \\
\text { Business Agency of } \\
\text { Lower Austria }\end{array}$ & Austria & Niederösterreich \\
\hline 5. & CO2FREE & $\begin{array}{l}\text { Cooperating } 2 \text { Foster } \\
\text { Renewables and } \\
\text { Energy Efficiency }\end{array}$ & $\begin{array}{l}\text { European Regions } \\
\text { Network for the } \\
\text { Application of } \\
\text { Communications } \\
\text { Technology, } \\
\text { Letterkenny, Co. } \\
\text { Donegal }\end{array}$ & Ireland & $\begin{array}{l}\text { Border, } \\
\text { Midland and } \\
\text { Western }\end{array}$ \\
\hline 6. & DANTE & $\begin{array}{l}\text { Digital Agenda for } \\
\text { New Tourism } \\
\text { Approach in European } \\
\text { Rural and Mountain } \\
\text { Areas }\end{array}$ & $\begin{array}{l}\text { Province of Turin, } \\
\text { Torino }\end{array}$ & Italy & Piemonte \\
\hline 7. & e-CREATE & $\begin{array}{l}\text { Cultural Routes } \\
\text { Entrepreneurship and } \\
\text { Technologies } \\
\text { Enhancement }\end{array}$ & $\begin{array}{l}\text { Ministry of Regional } \\
\text { Development and } \\
\text { Transport Saxony - } \\
\text { Anhalt, Magdeburg }\end{array}$ & Germany & Sachsen-Anhalt \\
\hline 8. & EuroScreen & $\begin{array}{l}\text { European screen } \\
\text { destinations }\end{array}$ & $\begin{array}{l}\text { Film London Ltd., } \\
\text { London }\end{array}$ & $\begin{array}{l}\text { United } \\
\text { Kingdom }\end{array}$ & Inner London \\
\hline 9. & GRISI PLUS & $\begin{array}{l}\text { Geomatics Rural } \\
\text { Information Society } \\
\text { Initiative PLUS }\end{array}$ & $\begin{array}{l}\text { Gers Chamber of } \\
\text { Commerce and } \\
\text { Industry }\end{array}$ & France & Midi-Pyrénées \\
\hline 10. & HISTCAPE & $\begin{array}{l}\text { HISTorical assets and } \\
\text { related landsCAPE }\end{array}$ & $\begin{array}{l}\text { Rural Development } \\
\text { Styria, Graz }\end{array}$ & Austria & Steiermark \\
\hline 11. & Hybrid Parks & $\begin{array}{l}\text { Hybrid Parks: } \\
\text { Combining abilities, } \\
\text { creating synergies and } \\
\text { enhancing the } \\
\text { performance of parks } \\
\text { for sustainable local } \\
\text { and regional } \\
\text { development policies }\end{array}$ & $\begin{array}{l}\text { Schloss Dyck } \\
\text { Foundation. Centre } \\
\text { for Garden Art and } \\
\text { Landscape Design, } \\
\text { Jüchen }\end{array}$ & Germany & Düsseldorf \\
\hline 12. & I-SPEED & $\begin{array}{l}\text { Information Society } \\
\text { Policies for } \\
\text { Sustainable European } \\
\text { Economic } \\
\text { Development }\end{array}$ & $\begin{array}{l}\text { City of Venice, } \\
\text { Venice }\end{array}$ & Italy & Veneto \\
\hline 13. & ICER & $\begin{array}{l}\text { Innovative Concept of } \\
\text { Eco-accommodation } \\
\text { approach in rural } \\
\text { Regions: Public } \\
\text { support policies for } \\
\text { eco-investors }\end{array}$ & $\begin{array}{l}\text { Regional Committee } \\
\text { for Tourism } \\
\text { Development of } \\
\text { Auvergne, Aubiere }\end{array}$ & France & Auvergne \\
\hline
\end{tabular}




\begin{tabular}{|c|c|c|c|c|c|}
\hline 14. & ICT-VN & $\begin{array}{l}\text { Promotion of ICTs } \\
\text { usage by SMEs as an } \\
\text { enabler of Value } \\
\text { Networks }\end{array}$ & $\begin{array}{l}\text { Dedalo Foundation } \\
\text { for the information } \\
\text { Society, Tudela }\end{array}$ & Spain & $\begin{array}{l}\text { Comunidad } \\
\text { Foral de } \\
\text { Navarra }\end{array}$ \\
\hline 15. & IPP & $\begin{array}{l}\text { Interregional } \\
\text { Partnership Platform }\end{array}$ & $\begin{array}{l}\text { Ministry of Science } \\
\text { and Economy of } \\
\text { Saxony-Anhalt, } \\
\text { Magdeburg }\end{array}$ & Germany & Sachsen-Anhalt \\
\hline 16. & LakeAdmin & $\begin{array}{l}\text { Regional } \\
\text { administration of lake } \\
\text { restoration initiatives }\end{array}$ & $\begin{array}{l}\text { Finnish Environment } \\
\text { Institute, Helsinki }\end{array}$ & Finland & Etelä-Suomi \\
\hline 17. & LOCFOOD & $\begin{array}{l}\text { Local food as engine } \\
\text { for local business }\end{array}$ & $\begin{array}{l}\text { Nordland County } \\
\text { Council, Bod } \varnothing\end{array}$ & Norway & Nordland \\
\hline 18. & MOG & Move on green & $\begin{array}{l}\text { Provincial } \\
\text { Government Teruel, } \\
\text { Teruel }\end{array}$ & Spain & Aragón \\
\hline 19. & NOSTRA & Network of STRAits & $\begin{array}{l}\text { Pas-de-Calais County } \\
\text { Council, Arras }\end{array}$ & France & $\begin{array}{l}\text { Nord - Pas-de- } \\
\text { Calais }\end{array}$ \\
\hline 20. & PIKE & $\begin{array}{l}\text { Promoting Innovation } \\
\text { and the Knowledge } \\
\text { Economy }\end{array}$ & $\begin{array}{l}\text { ERNACT EEIG, } \\
\text { Letterkenny }\end{array}$ & Ireland & $\begin{array}{l}\text { Border, } \\
\text { Midland and } \\
\text { Western }\end{array}$ \\
\hline 21. & PRESERVE & $\begin{array}{l}\text { Peer Reviews for } \\
\text { Sustainable Eco- } \\
\text { Regions via Europe }\end{array}$ & $\begin{array}{l}\text { Assembly of } \\
\text { European Regions, } \\
\text { Strasbourg }\end{array}$ & France & Alsace \\
\hline 22. & $\begin{array}{l}\text { Robinwood } \\
\text { PLUS }\end{array}$ & $\begin{array}{l}\text { Apply participatory } \\
\text { forest planning for } \\
\text { sustainability: } \\
\text { Robinwood Plus }\end{array}$ & $\begin{array}{l}\text { Liguria Region - } \\
\text { Environment } \\
\text { Department, Genova }\end{array}$ & Italy & Liguria \\
\hline 23. & $\begin{array}{l}\text { SMART } \\
\text { EUROPE }\end{array}$ & $\begin{array}{l}\text { Smart strategies to } \\
\text { create innovation- } \\
\text { based jobs in regions } \\
\text { of Europe }\end{array}$ & $\begin{array}{l}\text { Province of } \\
\text { Flevoland, Lelystad }\end{array}$ & $\begin{array}{l}\text { Nether- } \\
\text { lands }\end{array}$ & Flevoland \\
\hline 24. & SMART+ & $\begin{array}{l}\text { Mini-Programme for } \\
\text { SME Innovation and } \\
\text { Promotion of RTD }\end{array}$ & $\begin{array}{l}\text { Aragonese } \\
\text { Federation of } \\
\text { Municipalities, } \\
\text { Regions and } \\
\text { Provinces, Zaragoza }\end{array}$ & Spain & Aragón \\
\hline 25. & SURF-Nature & $\begin{array}{l}\text { Sustainable Use of } \\
\text { Regional Funds for } \\
\text { Nature }\end{array}$ & $\begin{array}{l}\text { Federal Environment } \\
\text { Agency Austria, } \\
\text { Wien }\end{array}$ & Austria & Wien \\
\hline
\end{tabular}




\begin{tabular}{|c|l|l|l|l|l|}
\hline 26. & SUSTAIN & $\begin{array}{l}\text { Assessing } \\
\text { sustainability and } \\
\text { strengthening } \\
\text { operational policy }\end{array}$ & $\begin{array}{l}\text { Coastal \& Marine } \\
\text { Union (EUCC), } \\
\text { Leiden }\end{array}$ & $\begin{array}{l}\text { Nether- } \\
\text { lands }\end{array}$ & Zuid-Holland \\
\hline 27. & TOURAGE & $\begin{array}{l}\text { Developing Senior } \\
\text { Tourism in Remote } \\
\text { Regions }\end{array}$ & $\begin{array}{l}\text { Regional Council of } \\
\text { North Karelia, } \\
\text { Joensuu }\end{array}$ & Finland & Itä-Suomi \\
\hline 28. & TRAP & $\begin{array}{l}\text { Territories of Rivers } \\
\text { Action Plans }\end{array}$ & $\begin{array}{l}\text { Kainuun Etu ltd, } \\
\text { Kajaani }\end{array}$ & Finland & Itä-Suomi \\
\hline 29. & WF & Waterways Forward & $\begin{array}{l}\text { Dutch Recreational } \\
\text { Waterways } \\
\text { Foundation, } \\
\text { Driebergen }\end{array}$ & $\begin{array}{l}\text { Nether- } \\
\text { lands }\end{array}$ & Utrecht \\
\hline 30. & ZEN & $\begin{array}{l}\text { Zero-Impact Cultural } \\
\text { Heritage Event } \\
\text { Network }\end{array}$ & $\begin{array}{l}\text { Sviluppumbria - } \\
\text { Regional } \\
\text { Development } \\
\text { Agency for } \\
\text { Economic } \\
\text { Promotion, Perugia }\end{array}$ & Italy & Umbria \\
\hline
\end{tabular}

\section{Source: own work}

In terms of the importance of tourism in the tourism projects, 30 projects were categorized for this article (Figure 10). Three project types were distinguished:

$\mathrm{T} 1$ - projects where tourism is marginal;

T2 - projects where tourism is significant;

T3 - projects where tourism plays a leading role;
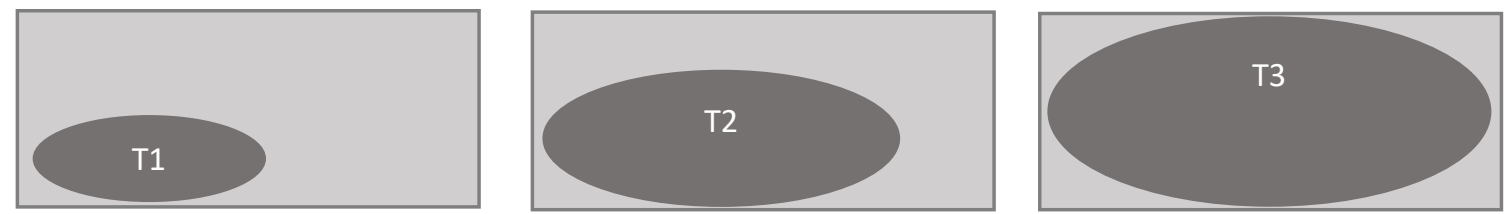

Figure 10: Types of tourism projects

The analysis of the projects in view of tourism issues (Figure 11) shows that the projects where tourism is marginal (T1) account for the largest group (47\%). The projects where tourism is significant (T2) account for $33 \%$ of the analysed group. The smallest group (20\%) contains the projects where tourism plays a leading role (T3). 


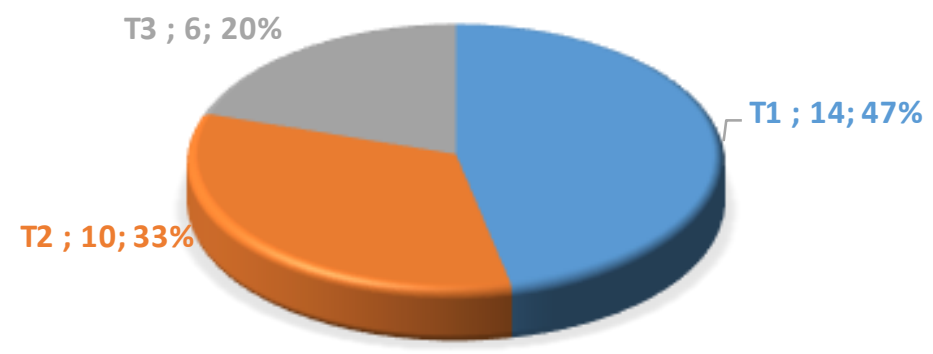

Figure 11: Structure of INTERRREG IVC tourism projects in numbers and percentage

Tourism projects $\mathrm{T} 1, \mathrm{~T} 2, \mathrm{~T} 3$ account in total for $3 \%, 5 \%$, and $7 \%$ respectively of all INTERREG IV C projects in this group (Figure 12).

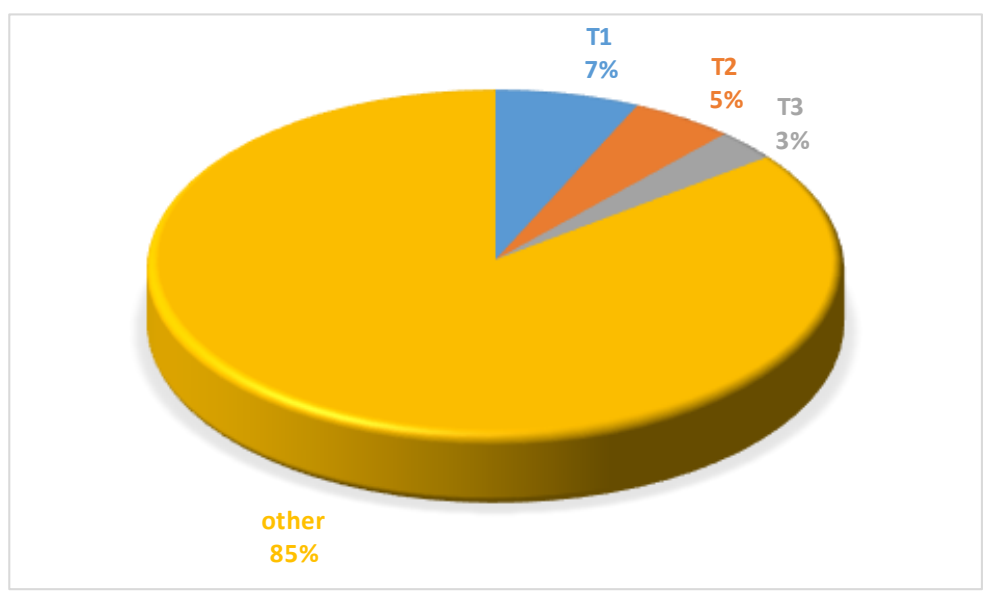

Figure 12: Tourism projects in INTERREG IV C projects in numbers and percentage

Nearly the same number of tourism projects was implemented under priorities P1 (53\%) and P2 (47\%). Almost all tourism projects (93\%) were "Regional Initiative Projects" (RIP). The tourism projects were part of nine out of ten themes of the programme (Figure 13). The following themes had the largest number of projects: Entrepreneurship and SMEs (E/SMEs), Information Society (IS), Cultural heritage and landscape (CH/L). The only theme that was not included in the tourism projects was Natural and technological risks, climate change (NTR).

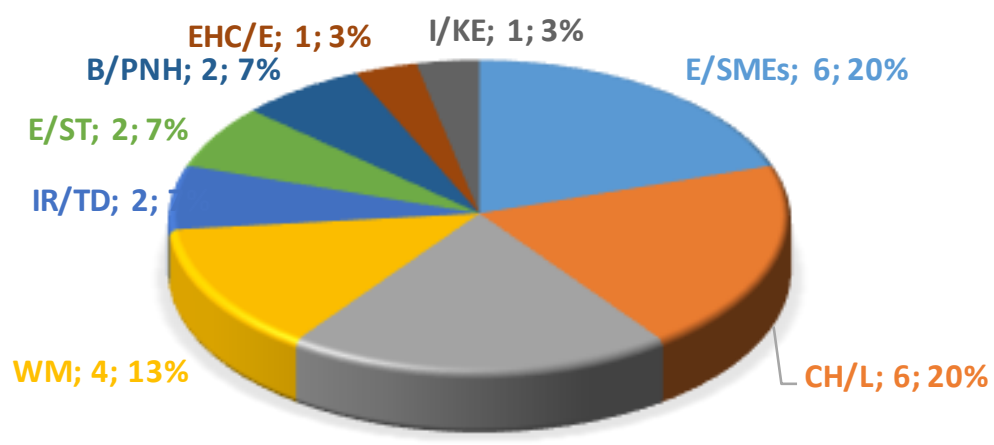

IS; $6 ; 20 \%$

Figure 13: Themes of IINTERREG IVC tourism projects in numbers and percentage

The budget of these 30 tourism projects was EUR 45,236,365.99. This means that statistically every project received support at the amount of EUR 1.51 million. 
In fact, the project budgets were very similar.

The smallest budget was EUR 0.89 million, while the biggest budget was EUR 3.23 million. Three hundred and sixty partners participated in all these projects. On average, 12 partners participated in each project. Statistically, each of the partners received support at the amount of EUR 125.660. The actual number of partners in the programmes varied between 6 and 18. The partners participating in the tourism projects were from 31 countries. They represented all $27 \mathrm{EU}$ states at that time as well as Norway and Switzerland. In addition, partners from Serbia and Albania were allowed to participate in the project. The number of partners from individual countries varied significantly between 1 and 40. Most partners were from Italy, Spain, and Greece (Figure 14).

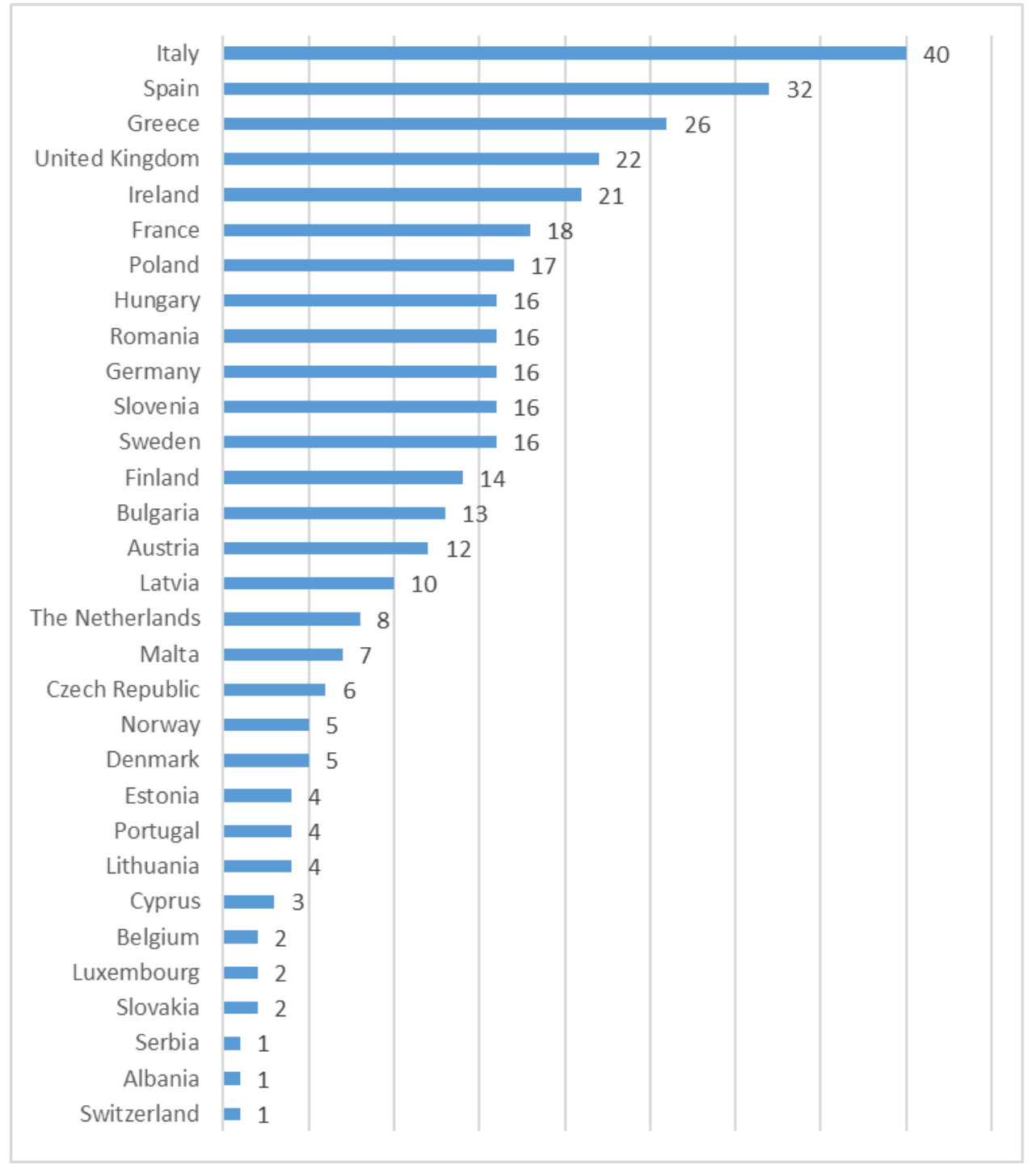

Figure 14: The number of partners from individual countries in the tourism projects

Based on the analysis of project descriptions, the projects were compared in terms of material scope in three categories of tourism projects.

1. Projects where tourism is marginal

The projects that included tourism topics varied significantly and covered a wide range of issues such as 
- tourism in interregional cooperation (P. IPP);

- tourism in cluster cooperation (P. CLUSTERIX);

- $\quad$ tourism as "entrepreneurial initiatives" (P. B2N);

- tourism in the development of information and communication technologies (P. ICT$\mathrm{VN})$;

- tourism in the development of sustainable transport (P.MOG);

- tourism in the development of cultural heritage (P. ZEN).

In these projects tourism issues appeared in particular areas such as forest areas (P. Robinwood PLUS), valuable natural areas (P. SURF-Nature), coastal regions (p. SUSTAIN), waterways ( $p$. WF), straits (P. NOSTRA).

In some of the projects, even in those that focused on issues not related to tourism, only a statement appeared that they would contribute to tourism development (P. CO2FREE, P. PIKE, P. SMART EUROPE).

2. Projects where tourism is significant

Tourism was emphasised in projects promoting innovations (such as P. I Speed). The project SMART+ played an important role in promoting the good practices of innovative tourism, which was called "smart tourism". The effect of this project was a collection of "good practices for destination management systems to increase attractiveness of tourism destinations".

The GRISI PLUS project indicated examples of using geomatics for tourism development; innovative ways of protecting heritage and the development of cultural tourism were described in the HISTCAPE project.

In projects related to local development (P ICER) tourism was considered one of the most important developmental factors. The LOCFOOD project showed the synergy between the tourism market and the local food market.

Tourism issues also appeared in projects on sustainable development. These projects concerned land areas (P. Hybrid Parks) and water areas (P. LakeAdmin, P. TRAP). The PRESERVE project presented the idea of "ecoregions", where tourism and ecological functions played an important role in sustainable development.

3. Projects where tourism plays a leading role

These projects focused on selected forms of tourism where the social aspect played a leading role.

These projects included:

1. The CERTESS project aimed at setting up a common methodological framework on how to develop, manage and enhance European Cultural Routes (ECRs), by utilising reference development and governance instruments targeted to foster sustainable cultural tourism. Thirteen partners participated in this project. It allowed to formulate 11 Route Implementation Plans. In addition, 84 Governance Instruments were documented and organized according to a classification scheme reflecting the structure of the Route Implementation Plan and the CERTESS Database Knowledge Platform supporting it. 
The project's coordinator was the European Institute of Cultural Routes - an institution established under the auspices of the Council of Europe. One of its statutory tasks is to promote cultural tourism.

2. The CHARTS project focused on the role of culture and heritage in the formulation and delivery of added-value to regional strategies for sustainable tourism development and integration into local, regional, national and EU policies.

Partners shared experience on how improved management of cultural tourism destinations contributed to protection and enhancement of cultural heritage \& landscape, as well as sustainable regional development policies, especially in relation to challenges of climate change and the economic crisis. 12 Good Practices have been identified, reviewed, analysed, discussed, documented and exchanged between the partners. Thirteen partners participated in the project. One of the partners was the European Cultural Tourism Network (ECTN), an organization associating tourism and cultural institutions from Europe.

3. The DANTE project aimed to promote a new regional policy approach to designing knowledge-based plans for the tourism sector. The objective was to improve the effectiveness of regional innovation policies by enhancing the role of ICT in tourism industry in rural and mountain areas. The project involved 14 partners. The partners participated to 34 external events around Europe and organised 8 dissemination events. The Good Practices Guide we published on Dante website.

4. The e-CREATE project aimed to promote the adoption of modern communication technologies aiming to enhance entrepreneurship in tourism-related sectors of Europe's rural areas. The idea of the project was born among European regions who are partly members of the Transromanica and CrossCulTour transnational project network. Thirteen partners participated in this project. Outputs of the project activities included a brochure titled "Are you CReATIVE?" showcasting 13 good practices selected out of a total of 40 investigated approaches and 4 online guidebooks on legal and marketing aspects regarding the introduction of apps for mobile devices to promote rural tourism, the relevance of open data in tourism.

5. The TOURAGE project aimed to improve sustainable regional economy by developing senior tourism and to support active and healthy aging through the exchange of good practices and. The project focused on identifying good practices on senior tourism and started to analyse regional trends in tourism and demographic change experiences between partner regions. 13 partners cooperated in this project.

One of its effects was the publication "Good Practices for Senior Tourism" containing 55 good practices. TOURAGE was also involved in the European Commission's senior tourism group of experts that proposed actions to increase senior tourism flows in the low and medium seasons within EU countries and from 3rd countries.

EuroScreen was different from the other projects. It was rather a marketing project. Nine partners participated in it. The coordinator was Film London - a media agency - sustaining, promoting and developing London as a major international film-making and film cultural capital. The overall purpose was to maximise the economic synergies between the screen and tourism leading to the sectors' increased innovation, competitiveness and growth in 8 selected regions across Europe. It had been demonstrated that the representation of cities and regions in 
audiovisual media (films, tv series, adverts, internet, etc.) was both important in strengthening and sustaining the diversity of different EU states' culture, and increasingly, having a substantial economic impact on tourism.

\section{TOURISM IN GOOD PRACTICES}

One of the most important effects of INTTEREG IVC is a good practices database. It is an electronic document available on the programme's website. It contains 1628 practices. It must be stressed that these are only examples of good practices selected by the Programme Managing Authority.

Based on an analysis of the content of the good practices, 60 projects with 150 practices in total were distinguished. The number of good practices presented in the projects varied from one to nine. ICER (Innovative Concept of Eco-accommodation approach in rural Regions: Public support policies for eco-investors) was a project that contained nine practices.

The topics of good practices included actions such as marketing as well as partnership and collaboration; they focused on sustainable tourism, heritage, and cultural tourism.

The good practices contained topics such as environment protection as well as information and communication technology. Actions in the accommodation sector and food and catering were also emphasised.

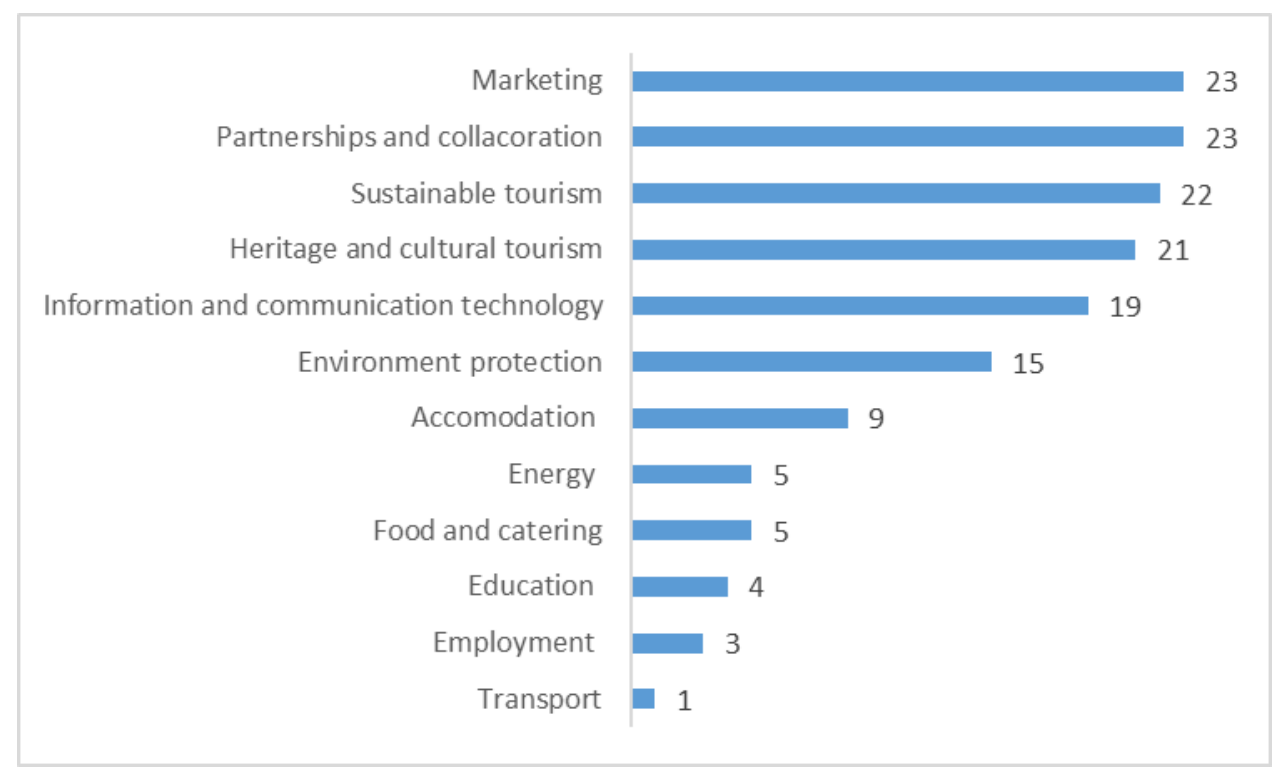

Figure 15: Good practices topics

\section{TOURISM IN THE PROMOTIONAL ACTIVITIES OF THE PROGRAMME}

The promotional campaign of INTERREG IVC covered a range of actions informing about the achievements of the projects. The release of four thematic publications was important.

1. Experience - Cooperation - Development Regions of enlarged Europe sharing solutions [2009]. In this publication INTERREG III tourism projects were only described, the tourism achievements of INTERREG IVC were omitted. 
2. Better Policies through Interregional Cooperation: experience and good practice from North area countries [2011]. This publication lists INTERREG IVC projects that contributed to tourism development. It included the following projects: B2N, ICER, ICT-VN, I-SPEED, EUROSCAPES, PRESERVE, SIGMA for Water, WF, REVERSE, RTF.

3. NTERREG IVC West area regions - Benefitting from interregional cooperation [2012]. Two projects, ICT-VN and FRESH, appeared in this publication.

4. Interregional cooperation in South area region [2013]. There were no tourism projects in this publication.

In addition, information about these projects appeared in publications defined as general:

1. Key features of Capitalisation projects [2009]. The PIKE project was listed there.

2. Solidarity works! How Regions improve thanks to cooperation [2011]. This publication devotes a great deal of attention to the tourism cooperation of border regions in Western Europe under the NEEBOR project. It showed that the programmes of cross-border cooperation made a significant contribution to tourism development. Another project presented in this publication was FLIPPER. It discussed the relations between tourism and the development of sustainable transport.

As part of promotional activities an interactive online site "Stories of Changing Regions" was created. In 2016 it is no longer available online. However, from the information about the content of that site on the INTERREG IVC website, it appears that it raised tourism issues.

Representatives of INTERREG IVC developed also an exhibition which consisted of 11 interactive thematic stands and gave an overview of about 60 good practices identified by the projects. This exhibition omitted, however, tourism issues.

\section{CONCLUSIONS}

The interregional cooperation programme significantly differs from other programmes of territorial cooperation. It covers the biggest eligible area, but has the smallest budget. Since it is a non-investment programme, its effects are non-material, so they are more difficult to measure.

The projects implemented from the programme funds focus mainly on activities related to exchanging good practices as well as educational and promotional projects.

Unlike other programmes, tourism was not considered a priority. Potential beneficiaries were discouraged from dealing with tourism issues in these projects.

Thus, it could seem that the programme is not able to contribute to tourism development. But the results of the research conducted by the authors according to the adopted model proved that the programme enabled to complete tourism projects through the creative use of INTERREG IVC priorities and operational objectives.

Like in the case of other programmes, the authors were faced with the problem of identification of tourism projects. Since tourism was not included either in priorities or operational objectives, it was necessary to analyse the content of project descriptions. In this way 30 projects were identified as tourism projects with a total budget of EUR 45,236,365.99. A 
distinctive feature of these projects was the fact that a lot of partners participated in the projects. The partners participating in these projects were usually from Italy, Spain, and Greece.

The good practices database played a significant role in determining the role of the programme in tourism development. The analysis of its documents allowed to identify 60 tourism-related good practices. These practices focused on cultural and sustainable tourism. They also concerned a range of other issues, including problems related to cooperation of stakeholders and marketing tourism-related activities. Among six tourism projects classified to category T3 by the authors (projects where tourism plays a leading role) the CERTESS project (Cultural European Routes - Transferring Experiences, Sharing Solutions) deserves a special focus. "The partners intended to make their activities sustainable by integrating their Plans into a European Cultural Routes strategy for establishing Europe as a first cultural tourism destination in the world" [Capp 2012]. The project can be a standard for using the interregional cooperation programme for tourism development.

The influence of interregional cooperation on tourism development was also noticed by the representatives of the programme managing authority; materials and tools promoting the achievements of the programme prove that. The majority of the programme tools, the activities implemented as well as good practices and achievements are digital. It would be advisable that despite the fact that INTERREG IV C was completed and INTERREG Europe appeared in its place, information about the programme should be available to enable to conduct research on interregional cooperation.

\section{REFERENCES}

BALAZ V., (2006), Slovakia: EU accession and Cross-border Travel, in: Hall D., Smith M., Marciszewska B., (eds.), Tourism in the New Europe The challenges and opportunities of EU enlargement, $C A B$ International Publishing, London.

Better Policies through Interregional Cooperation: experience and good practice from north area countries (2011), INTERREG IVC European Regional Development Fund, European Union.

BUCZKOWSKI Ł., ŻUKOWSKI L. (2014), Formy współpracy międzynarodowej lokalnych jednostek samorządu terytorialnego, in: Feret E., Niemczuk P. (eds.), 10 lat doświadczeń polskiego samorządu terytorialnego w Unii Europejskiej, Wyższa Szkoła Prawa i Administracji RzeszówPrzemyśl, Rzeszów-Przemyśl.

CAPP A., (2012), Cultural European Routes: Transfer Experiences, Share Solutions (Certess), "International Journal of Heritage in the Digital Era January 2012" no 1, pp. 175-179.

CASTRO J., (1999), The Other Dimension of Third Level Politics in Europe: The Congress of Local and Regional Powers of the Council of Europe, in: Aldecoa F., Keating M. (eds.), Paradiplomacy in Action The Foreign Relations of Subnational Governments, Frank Cass Publishers, London Portland.

CELATA F., COLETTI R., (2015), Cross-border Cooperation along the EU's External Frontiers, in: Celata F., Coletti R., (eds.), Neighbourhood Policy and the Construction of the European External Borders, Springer, Cham Heidelberg New York Dordrecht London.

DEFFNER A, METAXAS T., (2010), Place branding, local identity and branding cultural images in Southern Europe: Nea Ionia, Greece and Pafos, Cyprus, in: Asworth G., Kavaratzis M., (eds.), 
Towards Effective Place Brand Management Branding European Cities and Regions, Edward Elgar, Cheltenham, Northampton.

DUHR S., COLOMB C., NADIN V., (2010), European Spatial Planning and Territorial Cooperation, Springer, Routledge, London and New York.

European Charter of Local Self-Government, (1985), European Treaty Series, No. 122

European Charter of Regional Self-Government (1997), Recommendation 34.

Experience - Cooperation - Development Regions of enlarged Europe sharing solutions (2009), INTERREG IVC European Regional Development Fund, European Union.

FABY H., (2016), Tourism policy tools applied by the European Union to support cross-border tourism, in: Wachowiak $\mathrm{H}$ (ed.)., Tourism and Borders Contemporary Issues Policies and International Research, Routledge, London and New York.

Fact Sheet; Historical view of Interreg / European Territorial Cooperation (2015), http://admin.interacteu.net/downloads/9301/INTERACT_Programme_Management_Handbook_ Factsheet_Historical_view_of_Interreg.pdf, (10.08.2016)

FESENMAIER D.,, O'LEARY J., UYSAL M., Recent Advances in Tourism Marketing Research, Routledge, New York London.

GROBELNA A., MARCISZEWSKA B., (2016), Work motivation of tourism and hospitality students: implications for human resource management, (in:) Bagnoli C., Mio Ch., Garlatti A., Massaro M. (eds.), Proceedings of the 8th European Conference on Intellectual Capital, ECIC 2016, Ca' Foscari University of Venice, Academic Conferences and Publishing International Limited, UK, pp. 95-103.

Guide on EU Funding for the tourism sector 2014-2020 (2016), European Union.

HASELSBERGER B., (2014), Decoding borders. Appreciating border impacts on space and people," Planning Theory \& Practice", Volume 15, Issue 4, pp. 505-526.

INTERREG IVC Programme Manual (2008), European Regional Development Fund, European Union.

INTERREG IVC West area regions - Benefitting from interregional cooperation (2012), INTERREG IVC European Regional Development Fund, European Union.

INTERREG IVC, http://www.interreg4c.eu/programme/funding/, (10.08.2016)

Interregional cooperation in South area region (2013), INTERREG IVC European Regional Development Fund, European Union.

Interregional Cooperation Programme INTERREG IVC Contributing to the European Commission Initiative "Regions for Economic Change", CCl 2007CB163P0046 Operational Programme 26 July 2007 Updated on 9 September 2011.

KENTNOWSKA K., (2012), Rozwój form współpracy samorządów na poziomie międzynarodowym, in: Dolnicki B., (ed.), Formy współdziałania jednostek samorządu terytorialnego, Lex a Wolters Kluwer Business, Warszawa.

Key features of Capitalisation projects (2009), INTERREG IVC European Regional Development Fund, European Union.

KUTUKOV A. (2006), Mezhregional'noe i prigranichnoe sotrudnichestvo gosudarstv - uchastnikov SNG: problemy i perspektivy: informacionno-analiticheskij doklad, Ispolnitel'nyj Komitet SNG, 
Moskva.

MARCUT M., (2015), The Socioeconomic Evolution of the European Union Exploring the Electronic Frontiers, Springer, Cham.

MC KEEVER P., LARWOOD J,, MC KIRDY A., (2006), Geotourism in Ireland and Britain, in: Dowling R., Newsome D., (eds.), Geotourism, Elsevier, Oxford.

MORATA F., NOFERINI A., (2013) The Pyrenees - Mediterranean Euroregion Functional Networks actor perceptions and expectations, in: BelliniN., Hilpert U., (eds.), Europe's Changing Geography: The Impact of Inter-regional Networks, Routledge, New York.

MORGAN N., (2010), Interregional cooperation: the benefits of sharing, http://2007-2013.atcz.eu/at-cz/downloads/Newsletters/INTERACT_Newsletter_No_6_September_2010.pdf (10.08.2016)

PERKOWSKI M. (2012), Główne podstawy prawnomiędzynarodowe aktywności zagranicznej samorządu terytorialnego w Europie, "Białostockie Studia Prawnicze", vol. 12, pp. 13-22.

PEROSA P., MENOTTI M., SARACENI F., (2008), II turismo accessibile La vacanza come diritti per tutti, in: Magistrali G., (ed.) Turismo sociale, Magioli S.p.A., Dogana

SCHUTZE R., (2015), European Union Law, Cambridge University Press, Cambridge.

SHARMA K. (2004), Tourism and Economic Development, Sarup and Sons, New Delhi.

STUDZIENIECKI T., (2015), Europejskie Ugrupowania Współpracy Terytorialnej ujęcie podmiotowe, przedmiotowe i przestrzenne, Academia Europa Nostra, Lubieszynek

STUDZIENIECKI T., (2016), The development of cross-border cooperation in an EU macroregion a case study of the Baltic Sea Region, "Procedia Economics and Finance" vol. 39, pp. 235 - 241.

SZYMANSKI J., (2011), The basic legal instruments for cross-border cooperation in the framework of the Council of Europe, "Białostockie Studia Prawnicze", No 9, pp. 90-109.

TEREM P., (2010), Transfrontier regions as Bridges of European Integration Process, in: Rouet G., Terem P., (eds.) Ukraine between integration and partnership, Etablissements Émile Bruylant, Bruxelles

WASSENBERG B., REITEL B., PEYRONY J., (2015), Territorial cooperation in Europe a historical perspective, Publications Office of the European Union, Luxembourg.

What is The INTERREG III Programme?, (2003), http://milieukontakt.net/archive/nl/act/docs/INTERREG\%20IIIC\%20Leaflet_E.pdf, (10.08.2016)

WILLIAMS H. (2012), The contribution of Spatial Planning to Social Cohesion in the European Union, in: Haller M. (ed.), The making of the European Union Contribution of the Social Sciences, Springer, Berlin Heidelberg New York. 